\title{
Lecturers' Method in Teaching Speaking at the University of Iqra Buru
}

\author{
Saidna Zulfiqar Bin Tahir ${ }^{1} \&$ Hanapi $^{2}$ \\ ${ }^{1}$ English Education Department of the University of Iqra Buru, Maluku, Indonesia \\ ${ }^{2}$ Art and Literature Faculty, University of Iqra Buru, Maluku, Indonesia \\ Correspondence: Saidna Zulfiqar Bin Tahir, English Education Department, the University of Iqra Buru, Ambon, \\ Maluku, Indonesia. Tel: 62-913-21990. E-mail: saidnazulfiqar@gmail.com
}

Received: October 23, 2016 Accepted: November 15, $2016 \quad$ Online Published: January 19, 2017

doi:10.5539/ijel.v7n2p73

URL: http://dx.doi.org/10.5539/ijel.v7n2p73

\begin{abstract}
This research aimed to reveal; (1) what method was applied by lecturers in teaching speaking; (2) how was the method applied in the classroom; and (3) how was the students' perception toward the implementation of the method. This research employed qualitative research. The respondent of the current research were two non-native English lecturers who taught at the University of Iqra Buru in Ambon, Maluku. To collect the data, three kinds of the instrument were used; observation, interview and documents examination. The data were analyzed using Miles \& Huberman technique who proposed three concurrent flows of action: a) data reduction; b) data display; and c) conclusion drawing/verification. The researchers found that; 1) The most of the method used in teaching speaking were grammar translation method, task-based, and lexical approach; 2) The implementing method in teaching speaking at the university consisted of material presentation and classroom discussion; 3) The students have bad perception toward the implementation of lecturers' method and learning activities in teaching speaking.
\end{abstract}

Keywords: lecturers' method, teaching speaking

\section{Introduction}

\subsection{Background}

The success in learning English, especially speaking is inseparable from the ability of lecturers who teach it to the students. Surprisingly, the students of English department at the University of Iqra Buru, $86 \%$ are not able to communicate in English well. This campus will generate prospective English teachers in Maluku, Indonesia. Surely, it will further impact on the quality of teachers in Maluku that were placed in the lowest rank based on the teacher competency test results (UKG), which only reached 34.5 percent since 2013 to 2015, and this result has put Maluku at the lowest position nationally (Kemendikbud, 2015). This problem must be solved so it will not collide with a profoundly negative impact on quality of education in Maluku.

Therefore, it is an urgency duty for the government, especially English lecturers to facilitate sufficient material and method of teaching which help the students in English learning. Generally, the Indonesian students faced the problems to communicate and express their idea in English because less of practicing, lack of vocabulary mastery, the problem in the organ of speak, and are passive to speak in the target language. As the result, they are fear in making mistakes and feeling inferior to speak English. Moreover, in teaching speaking, the lecturers must adopt and adapt varying method and activities that appropriate for the students to increase their components of English speaking skills in terms of fluency, accuracy, and comprehensibility.

Undoubtedly, lecturers are supposed to create a good learning atmosphere in which students feel pleasant and enjoyable in learning. The class will be comfortable and stimulating the learning process if the interaction between students and lecturer occurs spontaneously and naturally in acquiring the target language. Harmer (1998, p. 132) states that lecturer will want to promote as much English use as possible. So he/she will try and insist on the use of English in learning and oral production activities, but be more relaxed about it in order pedagogic situations, though he/she will encourage students to use it as possible. Ur (1996, p. 122) suggests appointing class monitors to remind students to keep using English. Furthermore, in promoting the use of the target language, Harmer (1998, p. 133) gives an illustration about one teacher who used to make students pay fine if 
they used the mother tongue in speaking activities. This an art of persuading students to use English, above all, it depends on the guidelines that were set, the agreement which lecturer made with students, and friendly encouragement and persuasion while activities are taking place. In regard to this case, the researchers had experienced when we held a speaking class in a university, we tried to make every student in our class to be active and to use the target language during the classroom interaction. Since it was not easy to do it, we made standard norms use English only and negotiated them to the students. At the first, mostly students felt enforced to adhere to the norms but after the class runs for several meetings they adapted to.

Those issues closely relate to the way lecturer organize classroom activities and perceive the individual steps connected. The well-organizing activities may essentially create the enjoyable learning process to motivate students in learning and improve their speaking performance. Moreover, the best lecturer does know their teaching material, but they also know a lot of teaching strategies and techniques. They never underestimate the power of the process to determine student learning output and outcome (Weimer, 2002). Thus, the learning strategies will guide the implementing of the methods and approaches in which they determine the appropriate techniques and tactics to be used by the lecturer in managing classroom activities that consequently affect the success of the language teaching and increasing learners' achievement (Bin Tahir, 2012). According to Gocer (2010, pp. 439-445), the strategy is actualized with the methods, and the methods are demonstrated with the techniques and tactics.

Finally, the researchers believe that no two lecturers embody a teaching method in the classroom in exactly the same way due to they have different knowledge, experience, and personality. A lecturer will have different concepts in related to the strategy in deciding how a speaking instruction is carried out. Therefore, the researchers were deeply moved to directly observe how an English speaking lecturers carry out his/her class to explore what method applied by them, to reveal how the implementation of the teaching method, and to know the students' perceptions toward the lecturers' method in teaching speaking.

The result of this study is expected theoretically to enrich insights into language teaching method. Practically, this study will enable the English language lecturer to implement the appropriate methods which help the students to increase their speaking skill.

\subsection{Theoretical Review}

Speaking is a real language tool to communicate and share the idea amongst people. It is fundamentally an instrument act as an interactive process of constructing meaning that involves producing and receiving and processing information (Finocchiaro in Sukrianto, 2005, p. 22; Burn \& Joyce, 1997, p. 63; Clark \& Clark in Goga, 2004, p. 27; Burn \& Joyce, 1997, p. 63).

Brown (2004, pp. 331-332) on his book "Teaching by Principles" wrote principles for teaching speaking skill, they are; 1) Focusing on fluency and accuracy which considering the learning objective; 2) Preparing intrinsically techniques to motivate the students in learning; 3) Authenticating language use in an appropriate contexts; 4) Providing appropriate feedback and correction; 5) Capitalizing on the natural link between speaking and listening; 6) Giving students opportunities to communicate in learning process as much as possible, and 7) Encouraging them to develop their speaking strategy and style.

A variety of teaching speaking methods has been applied by the lecturers. Some methods specifying on teaching general communication skills and emphasizing on the ability to express idea meaningfully and it can be understood by the interlocutor than to grammatical accuracy or perfect pronunciation. Others lecturers emphasis on accurate grammar and pronunciation from the very beginning or set out to teach the basic grammar in the first phase of learning a language (Richards \& Rogers, 1986, p. 20). Those methods are more explicitly described in Pollard's book (2008), they are:

\subsubsection{Grammar Translation Method}

This method focuses on studying written texts and translating them into the students' home language. It also emphasizes on learning grammar than to give attention to the pronunciation and spoken language. The major strategies implemented in GTM class are; translating a literary passage, reading comprehensive questions, finding the antonyms/synonyms of the words, cognates, deductive application of rules, filling in the blanks, memorizing vocabulary, and arranging words in simple sentences and compositions.

\subsubsection{Audio-lingual Method}

This method derived from of behaviorist paradigm which focuses on providing a stimulus to the students' respond; the correct of student response will be praised in order to strengthen the correct of language use and of course to reinforce discipline in learning. This method minimizes the explanations of grammar and emphasizes 
on repetition. Some basic strategies of this method can be found in some activities such as; memorizing the dialogue, peer dialog practicing, backward Build-up (Expansion) Drill, and Repetition Drill.

\subsubsection{Communicative Approach}

This method is based on the theory of language acquisition that pointed out to the language use rather than the study of grammar. It emphasizes on creating situations where the students have more opportunities to say something, just like as children do in their childhood. The strategies used in this method are; authentic material, scrambled sentence, language games, picture strip story, and role play.

\subsubsection{PPP (Presentation, Practice, and Production)}

This method might be similar to the audio-lingual through the use of pictures and focused learning. It can also be implemented through presentation and demonstration. The practice involves students using the target language in a controlled way. This might be implemented through drills, controlled written and speaking activities, and repetition. Production involves the students use the target language in the sentences.

\subsubsection{Task-based Learning}

In this method, the lecturer prepares a task for students to do individually or in a group on a subject or a topic that has not been studied yet in the classroom or the topic has been studied previously to strength their comprehension on the topic.

\subsubsection{ESA (Engage-Study-Activate)}

Engage refers to the getting the students' attention or interest and involving them in learning. The study involves focusing on a language point. It could be grammar, vocabulary, pronunciation or how a written text is organized. Activating refers to having students use the language in a reality context that is as close to real life as possible.

\subsubsection{Lexical Approach}

This method derived from the principle that grammar and vocabulary cannot be strictly separated as is often the case in traditional teaching methods. A further notion is that language is made up of lexical items using grammar to support them rather than being made up of grammatical structures incorporating lexis.

In brief, a lecturer must comprehend some teaching methods to implement in their class in order to reach the objective of learning to speak as the goal of oral interaction competency and to help students become functional in English or to use it spontaneously, naturally and effectively in day to day class life.

According to David \& Johnson (2001), many class activities those use cooperative learning in teaching speaking such as:

1) Jigsaw is grouping students into groups consist of five students in a group, each member of the group was given the task to study a topic and then teach it to members of the group, to help students work together in learning, and to determine what is important and how to teach;

2) Think-Pair-Share includes three steps of cooperative structures, during the first stage, each individual think quietly about the questions posed by the structure, the second step, each individual pair up and exchange ideas, and the third step, the pair share the responses with their group;

3) Numbered Head is a form of cooperative in which each member of the group is assigned the number 1,2,3,4, and then the teacher asked a question to the group. Each group works together to answer the question so that all group members may verbally answer the question. Then the teacher called the number (example: two) and each member of the group numbered two were asked to give an answer;

4) Round-Robin Brainstorming is class divided into small groups, with one person appointed as a recorder, the questions require a lot of answers and students give time to think the answer is, after the "think time", each member of the group requested answers and responses another group with Round-Robin style, then the recorder write down the answers of the group members;

5) Three-step Interview is each group member chooses another member to become a partner. In the first step, each student interviewed their partners by asking clarifying questions, in a second step, partners exchange the interviewing roles, and in the last step, each member of the group share the responses with their partner in the group;

6) Team-Pair-Solo which students work on tasks given by the teacher as a team, then with a partner, and in the end, the task was done individually. It is designed to motivate students to solve problems that initially are beyond their capabilities so that students are able to do more things with the help of others on issues that they can do 
themselves, first as a team and then in pairs and individually;

There are several characteristics that support the successful teaching of speaking, as suggested by Ur (1996. p. 120) are as follows:

1) Learners should be given plenty of opportunities to talk at a time that has been allocated to communicate in the classroom. Pollard $(2008$, p . 7) suggests $80 \%$ of the instructional time given to students to communicate and $20 \%$ is the time for the teacher to speak.

2) Participation in class discussion is not dominated by only minority talkative students, but all students have the same opportunity to speak, and contributions are distributed fairly.

3) Choosing an interested and new topic of learning so as to motivate students to contribute in achieving the learning objectives

Some previous researchers conducted the research on method, strategy, and classroom activities that will guide the lecturers to be successful in teaching speaking. As Ibadurrahman (2011) suggested the norms of behavior facilitate students to a lot of English exposure. Abassy (2011) conducted a survey on teaching strategies to develop ESL learners' linguistic abilities in Pakistan. Bin Tahir \& Aminah (2013) suggested the Facebook as the media to solve the lack of students' language mastery. Bin Tahir (2015a, pp. 174-181, and 2015b, pp. 296-306) suggested the use of social media such as Yahoo Messenger and Voice Chat to increase the students' speaking skill. Those studies related to the recent study in teaching speaking method and activity but it was different in paradigm whereby the researchers will observe the phenomenon directly and closely inside the speaking class subject to reveal the method implemented by the speaking lecturer.

\section{Method}

The researchers employed qualitative study by applying case study. Qualitative research is to collect data on the subject of research in order to obtain deep insight of the phenomena of interest. The data collection will analyze and interpret descriptively or narrative (Gay et al., 2006, p. 399). This research was conducted from January 11 2016 to August 162016 at English Educational Department of the University of Iqra Buru, Maluku, Indonesia.

\subsection{Participant (Subject) Characteristics}

The respondent of the current research were two of non-native English lecturers who teach in speaking class. Before deciding the respondent, the researchers did a primary study in intended the subject through an interview. Thus, we decided to take the two lecturers as the participant. The two lecturers are a male and a female. The male lecturer has the experience of teaching for forty-three years in SMPN 1 Namlea and teaches also in this university. While the female lecturer has eight years teaching English experience at SMPN 1 Namlea and teaches also in this university. The data gained from documentary record of the two lecturers and interview with them and the students.

\subsection{The Instrument of the Research}

The primary data collection instrument was the researchers themselves (Gay at al., 2006, p. 425) as an observer and an interviewer. It means that they decided what to be observed related to the problem statements then interpreted the data and confirmed the information about what have been observed by interviewing both the lecturers and students. The secondary instruments were an observation scheme and interview protocol.

\subsection{Data Collection Procedures}

Describe the procedures for selecting participants, including (a) the sampling method, if a systematic sampling plan was used; (b) the percentage of the sample approached that participated, and (c) the number of participants who selected themselves into the sample. Describe the settings and locations in which the data were collected as well as any agreements and payments made to participants, agreements with the institutional review board, ethical standards met, and safety monitoring procedures.

In collecting the data, the researchers employed three primary data collection techniques, as follows:

\subsubsection{Observation}

Here, the researchers as nonparticipant observation or external observation in which they did not directly involved in the situation being observed. They wrote field notes in all classroom activities during the speaking class. In addition, they also used a videotape to record verbal and nonverbal communication between lecturer and students which later be confirmed and adjusted to field notes, and also a volunteer assisted them in the interview section. 


\subsubsection{Interview}

The researchers interviewed both the lecturers and the students by using voice recorder. Type of the interview was a semi-structured in which some questions were prepared before interviewing and some additional question will be asked on the spot. The lecture's interview was used to collect qualitative data or confirmation toward what had been observed, it was done at the end of every meeting. And, student's interview was aimed to obtain the students' perceptions toward the implementation of the lecturer method in teaching speaking. The way to interview the students was by doing the group interview.

\subsubsection{Examining Records}

In addition to the observation and interview, the information was gathered through documentary evidence. This third primary data collection technique was examining records. The researchers examined various types of videotapes and audiotapes.

\subsection{Technique of Data Analysis}

Along with the description of subjects, give the size of the sample and number of individuals meant to be in each condition if separate conditions were used. State whether the achieved sample differed in known ways from the target population. Conclusions and interpretations should not go beyond what the sample would warrant.

The technique of qualitative data analysis uses the flow by Miles \& Huberman (1994) who suggested the three concurrent flows of action; a) data reduction; b) data display; and c) conclusion drawing/verification.

Data reduction is to summarize or to select the fundamental phenomena on teaching activities inside the classroom, to focus on the urgent categories of teaching method applied by the lecturer, to find the gist of the theme. The process of data reduction and analysis run in sequential and continuous procedure.

Data display applies in form of table, figure or chart to organize and arrange the pattern of the component so that it is easy to be understood. Drawing verification of the temporal conclusions and it could be changed when there is no evident support it in the further process of collecting data.

\section{Results}

The observation and interview data were derived from English teaching and learning activities inside the classroom at English Department of the University of Iqra Buru. Data on teaching speaking method were obtained from observation, interview, and recording of the teachers' interventions and classroom learning activities. Data were also obtained from the teaching document, and field notes. All of the data were analyzed to know the teaching method implemented in the learning process as can be seen in table 1.

Table 1. Lecturers' method in teaching speaking at the University of Iqra Buru

\begin{tabular}{|c|c|c|c|c|c|c|}
\hline No & Lecturers & Methods & $1^{\text {rst }}$ Meeting & $2^{\text {nd }}$ Meeting & $3^{\text {th }}$ Meeting & $4^{\text {th }}$ Meeting \\
\hline \multirow[t]{7}{*}{1} & \multirow[t]{2}{*}{ A } & Grammar translation method & $\sqrt{ }$ & $\sqrt{ }$ & $\sqrt{ }$ & $\sqrt{ }$ \\
\hline & & Audio-lingual method & - & - & - & - \\
\hline & \multirow[t]{5}{*}{$(\mathrm{AM})$} & Communicative Approach & - & - & - & - \\
\hline & & PPP (Presentation, Practice, and Production) & - & - & - & $\sqrt{ }$ \\
\hline & & Task-based learning & - & $\sqrt{ }$ & - & $\sqrt{ }$ \\
\hline & & ESA (Engage-Study-Activate) & - & - & $\sqrt{ }$ & - \\
\hline & & Lexical Approach & - & $\sqrt{ }$ & $\sqrt{ }$ & - \\
\hline \multirow[t]{7}{*}{2} & \multirow[t]{2}{*}{ B } & Grammar translation method & - & $\sqrt{ }$ & $\sqrt{ }$ & $\sqrt{ }$ \\
\hline & & Audio-lingual method & - & - & $\sqrt{ }$ & - \\
\hline & \multirow[t]{5}{*}{ (RB) } & Communicative Approach & $\sqrt{ }$ & - & - & - \\
\hline & & PPP (Presentation, Practice, and Production) & - & $\sqrt{ }$ & - & $\sqrt{ }$ \\
\hline & & Task-based learning & - & $\sqrt{ }$ & $\sqrt{ }$ & $\sqrt{ }$ \\
\hline & & ESA (Engage-Study-Activate) & - & - & $\sqrt{ }$ & - \\
\hline & & Lexical Approach & - & $\sqrt{ }$ & $\sqrt{ }$ & $\sqrt{ }$ \\
\hline
\end{tabular}

The checkmark $(\sqrt{ })$ in the table refers to existing method used by both lecturers, while the line (-) indicates the non-existing of learning method used by the lecturers at the university. The data shows that the most of the method used in teaching speaking were the grammar-translation method, which is the lecturer taught most of the written texts, asked the students to translate the paragraph into the students' home language and corrected grammatical mistakes. Task-based learning in which the lecturer gave a task for students to do individually that involves the topic has been studied before in the previous meeting to strength the students' mastery of the topic. 
Besides, both lecturers emphasized on lexical approach to made up of lexical items to support the use of grammar. The data indicated the lack of lecturers' method and low of creativity to build the enjoyable classroom atmosphere in teaching speaking which surely due to the decrease of students' speaking skill.

The lecturers used the method based on their personal experience in learning in which they considered as the effective method to apply it in teaching speaking for their students. They did not realize and know the name of the method they used. As stated by AB (lecturer A):

"I don't recognize what approach I used in teaching English. But I am convinced that those ways were effective in language teaching based on my experience in languages acquisition".

The statement is also in line to what argued by RB (lecturer B) who stated that:

"I don't know much whether the theories of learning or some theories of languages learning. I teach the students based on my experiences in language learning, and of course, I adopted the way of my teachers' style in teaching, I considered it as an appropriate Method".

The implementation of method in teaching and learning speaking at the university by both lecturers was also mixed some activities to support the learning process as can be seen in table 2 :

Table 2. The Implementation of teaching speaking method

\begin{tabular}{|c|c|c|c|c|c|c|}
\hline No & Lecturers & Activities in Teaching and Learning & $1^{\text {rst }}$ Meeting & $2^{\text {nd }}$ Meeting & $3^{\text {th }}$ Meeting & $4^{\text {th }}$ Meeting \\
\hline \multirow[t]{7}{*}{1} & \multirow[t]{2}{*}{$\mathrm{A}$} & Presentation & $\sqrt{ }$ & $\sqrt{ }$ & $\sqrt{ }$ & $\sqrt{ }$ \\
\hline & & Classroom discussion & - & $\sqrt{ }$ & $\sqrt{ }$ & $\sqrt{ }$ \\
\hline & \multirow[t]{5}{*}{$(\mathrm{AM})$} & Jigsaw & - & - & - & - \\
\hline & & Think-Pair-Share & - & - & - & $\sqrt{ }$ \\
\hline & & Round Brainstorming & - & - & $\sqrt{ }$ & - \\
\hline & & Three-step Interview & - & - & - & - \\
\hline & & Team-Pair-Solo & - & - & - & - \\
\hline \multirow[t]{7}{*}{2} & \multirow[t]{2}{*}{$\mathrm{B}$} & Presentation & $\sqrt{ }$ & $\sqrt{ }$ & $\sqrt{ }$ & $\sqrt{ }$ \\
\hline & & Classroom discussion & - & $\sqrt{ }$ & $\sqrt{ }$ & $\sqrt{ }$ \\
\hline & \multirow[t]{5}{*}{ (RB) } & Jigsaw & - & - & - & - \\
\hline & & Think-Pair-Share & - & - & $\sqrt{ }$ & - \\
\hline & & Round Brainstorming & - & - & - & $\sqrt{ }$ \\
\hline & & Three-step Interview & - & - & - & - \\
\hline & & Team-Pair-Solo & - & - & $\sqrt{ }$ & - \\
\hline
\end{tabular}

The data in table 2 shows that both lecturers applied some activities or a mix of some strategies in teaching and learning. The implementation of teaching speaking method at the university consisted of two main strategies; a) Material presentation in which the lecturers present their material to the students; b) Classroom discussion in which the lecturers gave the opportunities to the students to speak with their pair and support them to use short, clear, simple sentences and also correct the students' pronunciation mistakes.

Both lecturers were poor in implementing the method of teaching caused of their lack of knowledge in teaching speaking method. It can be seen through their statement via an interview:

"I knew some names of teaching method but I didn't know the way to implement those methods in teaching, so I teach the students as I feel comfortable" (Lecturer A). "I knew some methods, sometimes I would like to try implementing the other method with other activities in teaching speaking but I have no time to make the preparation" (lecturer B).

The lecturers' knowledge in implementing the method in teaching speaking will influence the students' speaking achievement. As the result, the students have low motivation in learning and lack of opportunities in practicing. Even the students have the good score in speaking subject, but they cannot communicate in English well. They perceived that the way of lecturers' method in teaching was boring and not creative to produce the new activity in strengthening the learning process as can be seen from the result of the interview with student (RS):

"I felt boredom join the speaking class because of the way of lecturers' method in teaching. I just come into the class, listen to the lecturers' presentation, and only to hear the smart students'discussion with the lecturer".

Base on the findings, the researchers concluded that the most of the method used in teaching speaking were grammar translation method, task-based learning, and lexical approach. The most activities implemented in learning process were the presentation and classroom discussion. Besides, the students have bad perception 
toward the implementation of lecturers' method and learning activities in teaching speaking.

\section{Discussion}

Based on the findings of the lecturers' method, the interpretation that can be drawn is that the most of the method used in teaching speaking were grammar-translation method which is the students were taught mostly in the written texts, they were asked to translate the text into Indonesian language and their grammar and pronunciation were corrected by the lecturer. While in task-based learning, the lecturer gave a task for students to do individually to strength their understanding of the topic. Besides, both lecturers emphasized on lexical approach to made up of lexical items using grammar. The data indicated the lack of lecturers' method in teaching speaking due to the decrease of students' speaking skill.

Despite no research findings on the effectiveness of the use of those methods in teaching speaking, it can be assumed that the lack of lecturers' method will influence the learning outcome. Perhaps, it is in line to what was suggested by Richards \& Rogers (1986, p. 20) and Pollard (2008) prioritize the ability to express oneself meaningfully and can be understood by the interlocutors than focusing on the grammatical accuracy or perfect pronunciation.

In teaching speaking, the lecturers didn’t consider varieties of strategies such teacher-student communication, students-student relationship, and daily routines inside and outside the classroom environment ranging from checking attendance, asking the students' condition, motivating the students, working with students, supporting the students to make their individual and group tasks, supporting learning activities with extracurricular programs outside the classroom as suggested by Ur (1996, p. 120) proposes some characteristics of successful speaking activity, namely: learners talk a lot, participation is even, and motivation is high. Of course, the students are eager to speak English because they are very interested in mastering a foreign language so that the lecturer should prepare interesting material for them to learn and prepare appropriate evaluation tools to measure the success of learning based on the learning objective.

The lecturers' method already affected the students' perception and motivation in learning because of the unsatisfactory or the degree of happiness they have in a relationship may affect the way they perceive the messages that he or she sends, degree of involvement with other person, expectations and the roles of students expect others to inhabit within society affects the lack of their perception.

Based on the data of this study, it can be concluded that the lack of students' mastery of English in communication caused the lack of lecturer knowledge and creativity in implementing appropriate methods in teaching speaking. As the result, the students felt boredom in joining the speaking class and they have low motivation in learning. However, the result of the present study is not intended to be generalized to all contexts/universities since the design of this research was qualitative approach and the aim of this study was to investigate the lecturers' method and it implementation in teaching speaking, and the students' perception toward the implementation of the method which can benefit the researchers to measure them quantitatively.

\section{Conclusion}

Based on the results, the researchers found that;

a. The most of the method used in teaching speaking were grammar-translation method, task-based learning, and lexical approach.

b. The implementation of teaching speaking method at the university consisted of two main strategies; a) Material presentation in which the lecturers present their material to the students; b) Classroom discussion in which the lecturers gave the opportunities to support students communication and correct the students' pronunciation mistakes.

c. The students have bad perception toward the implementation of lecturers' method and learning activities in teaching speaking.

Based on the conclusion above, the researchers gave some suggestion for the university, lecturers, and further researcher as follows:

a. The university must conduct a test in recruitment the lecturers, and the department should give the subject to the competence lecturer in that field of teaching and conduct the micro teaching training for the existed lecturers.

b. The lecturers must increase their knowledge and ability in teaching method and strategy in implementing teaching and learning in the classroom. 
c. For the next researcher to consider the lecturers' competence in teaching the subject before measuring the students' speaking skill achievement.

\section{Acknowledgments}

The research was financed by The Directorate General of Resources for Science, Technology and Higher Education of Indonesia. Thanks to English Department Lecturers and the Dean of Faculty for their contribution in finishing this article.

\section{References}

Bin Tahir, S. Z. (2012). Redefining Terms of Teaching and Learning Strategy, Method, Approach, Technique, and Model. Public lecture of Microteaching at English Education Department of University of Iqra Buru, November 01st 2012. Online. Retrieved from https://scholar.google.com/citations?view

Bin Tahir, S. Z. (2015a). Improving Students' Speaking Skill through Yahoo Messenger at University of Iqra

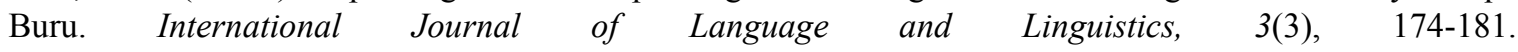
https://doi.org/10.11648/j.ijl1.20150303.20

Bin Tahir, S. Z. (2015b). Improving Students' Speaking Skill through Voice Chat at University of Iqra Buru. Journal of Modern Education Review, 296-306. https://doi.org/10.15341/jmer(2155-7993)/03.05.2015/009

Bin Tahir, S. Z., \& Aminah, A. (2014). Improving Students' Writing Skill through Facebook at University of Iqra Buru. Proceeding ICT for Language Learning (7th ed., pp. 235-241). Retrieved from https://books.google.co.id/books?isbn=8862925484

Brown, H. D. (2004). Language Assessment: Principle and Classroom Practices. San Francisco State University. London: Pearson Education, Inc.

Burns, A., \& Heken, J. (1997). Focus on Speaking. Sydney: Macquarie University.

David \& Johnson. (1977). Classroom Techniques: Foreign Language and English as Second Language. New York: Harcourt Brace Jovanovich Inc.

Gay, L. R. (2006). Educational Research. London : Longman.

Gocer, A. (2010). A Comparative Reasearch on the Effectivity of Cooparative Learning Method and Jigsaw Technique on Teaching Literary Genres. Educational Research and Review, 5(9), 439-445. Retrieved from http://www.academicjournals.org/ERR2

Goga, S. (2004). Improving the Speaking Skill of the First Year Students of SMK 1 Polewali Using Questioning Techniques. Unpublished Thesis. Makassar, Graduate Program UNM.

Harmer, J. (2001). The Practice of English Language Teaching (rev. ed.). London: Longman.

Harmers, J. (1998). The Practice of English Language Teaching. London: Longman.

Kemendikbud. (2015). Hasil Tabulasi nilai UKG 2015. (Online) Retrieved from http://reportaseguru.com

Miles, M. B., \& Huberman, A. M. (1994). Qualitative Data Analysis: An Expanded Sourcebook. London: Sage.

Pollard, A. (2008). Reflective Teaching: Evidence-informed Professional Practice (3rd ed.). London: Continuum International Publishing Group.

Richards, J. C., \& Theodore, S. R. (2001). Approaches and Methods in Language Teaching. Cambridge: Cambridge University Press. https://doi.org/10.1017/CBO9780511667305

Sukrianto, M. (2005). Speaking Activities Implemented by Senior High School Teachers in Classroom. EFL Asian Journal. Retrieved from http://www.asian-efl-journal.com/

Ur, P. (1996). A Course in Language Teaching: Practice and Theory. Cambridge: Cambridge University Press.

Weimer, M. (2002). Learner-centered Teaching. San Francisco: Jossey-Bass.

\section{Copyrights}

Copyright for this article is retained by the author(s), with first publication rights granted to the journal.

This is an open-access article distributed under the terms and conditions of the Creative Commons Attribution license (http://creativecommons.org/licenses/by/4.0/). 